\title{
BAT GUANO AND HISTORICAL EVIDENCE OF CLIMATE CHANGES IN THE WEST OF IRAN DURING THE LATE HOLOCENE (MEGHALAYAN STAGE)
}

\author{
POZNOHOLOCENSKE PODNEBNE SPREMEMBE V ZAHODNEM \\ IRANU: ANALIZE NETOPIRSKEGA GVANA IN ZGODOVINSKIH \\ DOKUMENTOV
}

\author{
Fariba ESFANDIARY DARABAD ${ }^{1}$, Mehran MAGHSOUDI ${ }^{2}$ \& Omid RAHIMI ${ }^{3}$
}

\begin{abstract}
UDC 551.583:631.854(55)"628.64"

Fariba Esfandiary Darabad, Mehran Maghsoud \& Omid Rahimi: Bat guano and historical evidence of climate changes in the west of Iran during the Late Holocene (Meghalayan Stage) An $86 \mathrm{~cm}$ thick sequence of bat guano layers in the Kolatarika Cave in Kurdistan province in the west of Iran was analysed. The sequence was radiocarbon dated and covers an age of approximately 4060 years. The results of geochemical data, statistical studies, along with the investigation, analysis and explanation of historical sources indicate the presence of warm and dry climate conditions between ca $2100 \mathrm{BC}$ and $800 \mathrm{CE}$. These were contemporaneous with the occurrence of periods of drought and famine during the Achaemenid and Sassanid empires, and might have been was one of the causes of their 'collapse. The existence of humid climate conditions between 800 and 1450 $\mathrm{AD}$ was contemporaneous with the period of Medieval Climate Anomaly and the historically documented prosperity of farms and agriculture during the Seljuk dynasties, the Samanids, and the rise of rainfall and river floods during the period of the $\mathrm{Ab}$ basid caliphate. The presence of cold and humid climate conditions between ca 1600 and $1750 \mathrm{AD}$ was consistent with the so-called Little Ice Age and the Maunder Minimum. After this period, the climate of this area changed to warm and dry which was contemporaneous with the occurrence of famine and subsequent droughts of the late Safavid and Qajar dynasties in Iran. Key words: palaeoclimate, geochemistry, Little Ice Age, Medieval Climate Anomaly, Kolatarika Cave, Iran.
\end{abstract}

Izvleček UDK 551.583:631.854(55)"628.64" Fariba Esfandiary Darabad, Mehran Maghsoud \& Omid Rahimi: Poznoholocenske podnebne spremembe $v$ zahodnem Iranu: analize netopirskega gvana in zgodovinskih dokumentov

$\mathrm{V}$ članku predstavimo analize 86 centimetrov debelega zaporedja plasti netopirskega gvana v jami Kolatarika v provinci Kurdistan, Zahodni Iran. Radiometrično ugotovljen starostni razpon gvana obsega zadnjih 4060 let. Statistična obravnava geokemičnih analiz gvana in raziskava zgodovinskih virov kažeta na toplo in suho podnebje v obdobju 2100 pr. n. št. in 800 n. št. To sovpada s sušami in lakoto v času ahamenidskega in sasanidskega cesarstva, kar je bil najverjetneje tudi vzrok njunega propada. Analize gvana kažejo na vlažno podnebje med 800 n. št. in 1450 n. št., kar ustreza srednjeveški podnebni anomaliji in obdobju razvoja kmetijstva in blaginje v času dinastij Seldžukov in Samanidov. Vlažno podnebje s padavinami je povzročilo tudi poplavljanje rek v času abasidskega kalifata. Hladno in vlažno obdobje med letoma 1600 in 1700 sovpada $\mathrm{z}$ malo ledeno dobo oziroma Maunderjevim minimumom. Po tem obdobju podnebje postane toplejše in bolj suho, kar spet sovpada $\mathrm{z}$ lakoto in sušami $\mathrm{v}$ poznem obdobju safavidske in kadžarske dinastije v Iranu.

Ključne besede: paleoklima, geokemija, mala ledena doba, srednjeveška podnebna anomalija, jama Kolatarika, Iran.

\footnotetext{
${ }^{1} 1$ University of Mohaghegh Ardabili, Islamic Respublic of Iran, e-mail: Esfandyari@uma.ac.ir

${ }^{2}$ University of Tehran, Islamic Respublic of Iran, e-mail: maghsoud@ut.ac.ir

${ }^{3}$ University of Mohaghegh Ardabili, Islamic Respublic of Iran, e-mail: omidrahimi@ut.ac.ir
} 


\section{INTRODUCTION}

To investigate climate and environmental changes of Late Holocene or Meghalayan Stage (International Union of Geological Sciences 2018) a variety of proxies and indicators have been used globally, including ice cores (DahlJensen et al. 1998; Johnsen et al. 2001), tree rings (Woodborne et al. 2015), speleothems (Fleitmann et al. 2007, 2009; Flohr et al. 2017), marine sediments (Mertens et al. 2012), lake sediments (Dean et al. 2015), river and alluvial deposits (Kaniewski et al. 2011), aeolian sediments and loess deposits (Yu \& Lai 2014), and landforms and glacial evidence (Sarkkaya et al. 2009).

Deposits of caves are particularly interesting, because caves are isolated areas and their physical and chemical conditions are fixed in short-term scales (Lauritzen 1993), and provide better preservation of remains for environmental reconstruction than those from the surface (speleothem, guano, sediments, etc.). Using these archives in caves to reconstruction ancient habitats and climate conditions in areas lacking other palaeoclimate data is very important (Onac et al. 2014). In caves all over the world, bats with a sufficient population produce large quantities of guano, sometimes accumulating up to 10 centimetres per year (Hutchinson 1950). These cave guano deposits have been investigated in order to reconstruct palaeoenvironment; for example, the Guano Geochemical studies of caves and sediments of caves for the reconstruction of palaeoenvironments by using multiple proxies, such as oxygen, carbon, and nitrogen stable isotopes (Forray et al. 2015; Royer et al. 2015; Onac et al. 2015; Campbell et al. 2017), pollen (Forray et al. 2015; Geantă et al. 2012; Batina \& Reese 2011), charcoal (Forray et al. 2015; Stoetzel et al. 2016), geochemistry (Wurster et al. 2017; Onac et al. 2015), radiocarbon dating of the guano deposits (Johnston et al. 2010), palynology (Batina

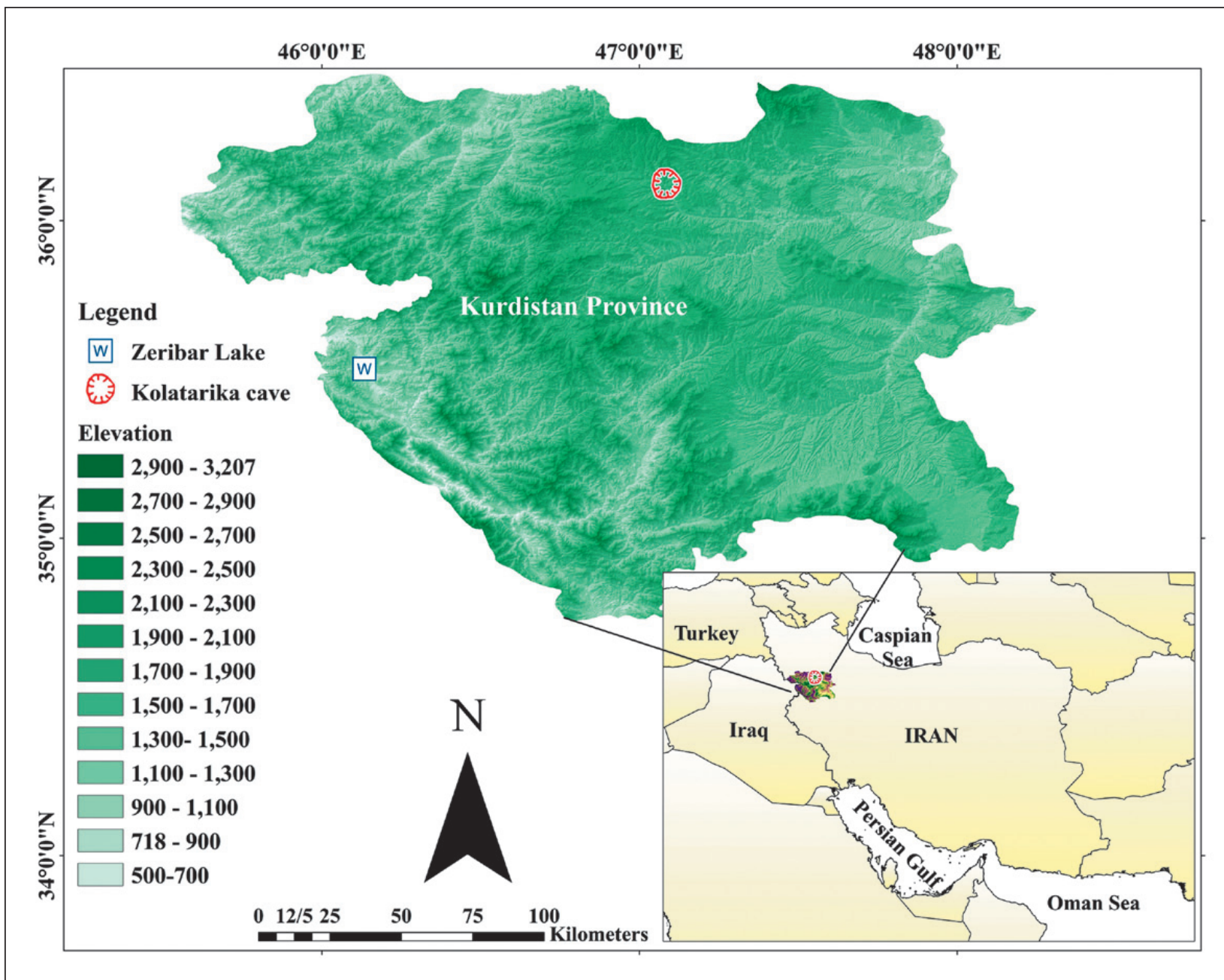

Fig. 1: Regional location map of the study area in the Iran. 
\& Reese 2011; Geantă et al. 2012), bats fossil (Stoetzel et al. 2016), palaeontology and palaeoecology (Widga \& Colburn 2015), many of the authors use a combination of multiple of these proxies.

Environmental and climate conditions are considered important factors in socioeconomic changes, immigration and even the collapse and decline of civiliza- tions (DeMenocal 2001). Although this is a global issue, in some semi-arid regions of the world, like Southwest Asia, where water is a key resource for the activity of civilizations, it is more vital (Kelley et al. 2015). For example, an increase in aridity is claimed to have been a crucial factor in the demise of Akkad empire about 4200 years ago (Weiss 2017), and to have led to crop failure, death

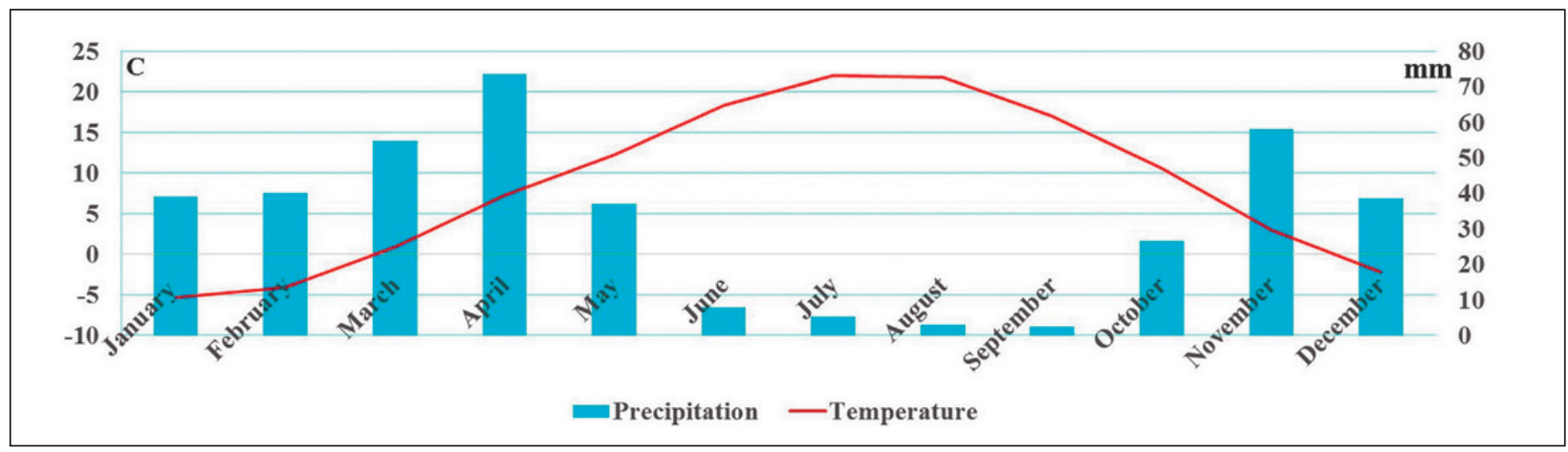

Fig. 2: Temperature and precipitation graphs in the study area (Zarineh Weather Station).

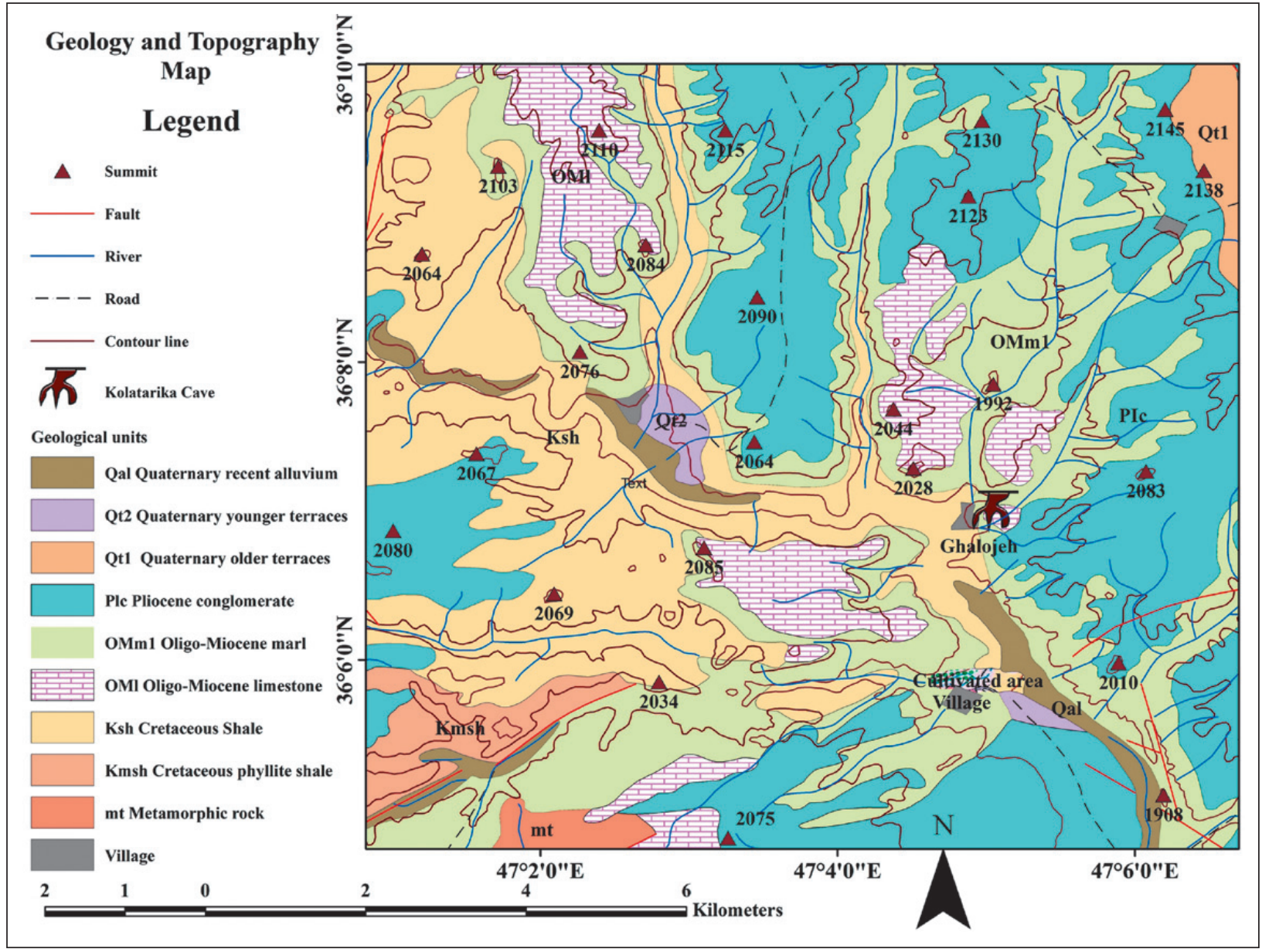

Fig. 3: Topographical and geological map of the study area. 


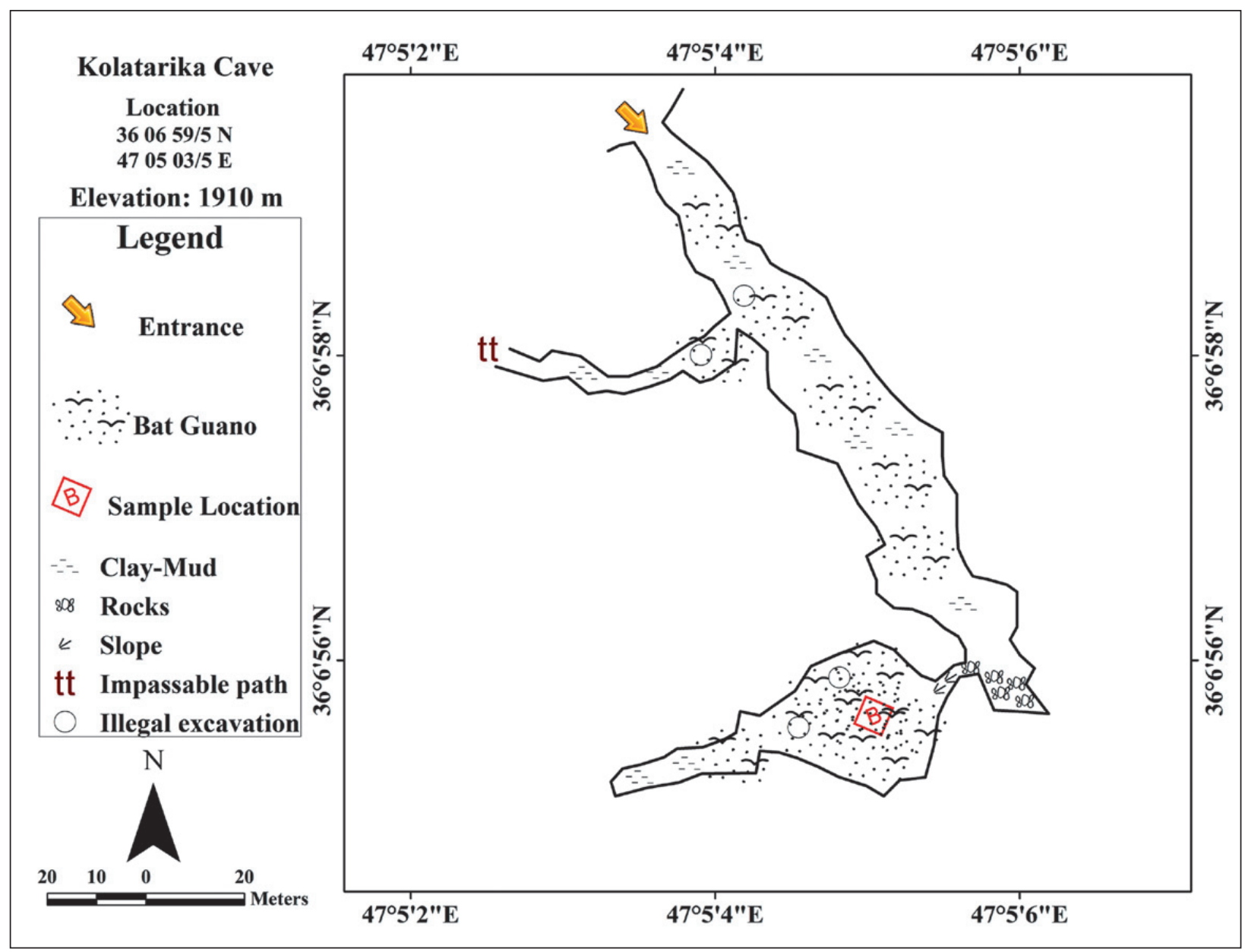

Fig. 4: Map of the Kolatarika Cave and location of sampling section.

and famine and migration in the Levant at the end of the Bronze Age about 3200 years ago (Kaniewski et al. 2013). The occurrence of severe drought might have led to a decline in the main population and collapse of Maya civilization (Medina-Elizalde et al. 2010). It has also been claimed that the occurrence of frequent drought has been one of the important factors in provoking struggle and ongoing conflicts in Syria (Kelley et al. 2015).

The western regions of Kurdistan in Iran are one of the most important areas for reconstruction and investigation of palaeoenvironment and palaeoclimate changes in the Late Pleistocene and Holocene.

Tab. 1: Characteristics of samples with determined age along with the age of $A M S{ }^{14} \mathrm{C}$, calibrated age as $(A D / B C)$, and the used age to draw age model to the depth of guano layers in the Kolatarika Cave of Qalujeh village.

\begin{tabular}{lccccccc}
\hline $\begin{array}{l}\text { Sample } \\
\text { name }\end{array}$ & Lab.no & $\begin{array}{c}\text { Depth } \\
(\mathbf{c m})\end{array}$ & $\begin{array}{c}\text { Sample } \\
\text { type }\end{array}$ & Age ${ }^{14} \mathrm{C}$ & Remark & pMC modern & $\begin{array}{c}\text { Age } \\
\text { (Cal. yrs. AD/BC) }\end{array}$ \\
\hline (Cal.yrs.BP)
\end{tabular}




\section{GEOGRAPHICAL AND GEOLOGICAL SETTING OF THE STUDIED CAVE}

Kolatarika Cave ("dark cave") is located in Qalujeh village, 35 kilometres from the Divandarreh in Kurdistan and western part of Iran (47 $\left.5^{\prime} 3.5^{\prime} \mathrm{E}, 36^{\circ} 6^{\prime} 59.5^{\prime} \mathrm{N}\right)$. It is 156 metres long and is located $1910 \mathrm{~m}$ a.s.l. in a small karstic area. The cave area is part of the Qizil Üzan basin, and Yulekeshti River flows through its western part (Fig. 1). The average annual precipitation is $396 \mathrm{~mm}$ and the average annual temperature is $9.9^{\circ} \mathrm{C}$ (Zarineh Weather
Station), with very cold winters and mild summers (Fig. 2 ). The spring is very short, while it has very long autumns and winters. According to De Martonne climate divisions, this area has a kind of Mediterranean climate. Lithologically, the cave is surrounded by creamy and pink fossiliferous limestone layers (Founoudi et al. 1998) (Fig. 3), and now there is no water in its corridors and galleries (Fig. 4).

\section{MATERIALS AND METHODS}

An $86-\mathrm{cm}$ deep vertical pit was dug by shovel into the bat guano. After cleaning, one section was sampled by using aluminium rectangle segments with the size of $20 \mathrm{~cm}$ length.

The age of three samples of bat guano bulk were determined using AMS dating after going through preparing stages of samples, including chemical pre-treating, a three stage process of treatment with acids and base solutions was carried out to remove organic and secondary carbonates, production of carbon dioxide and graphite in the Poznan Radiocarbon Laboratory in Poland (Goslar et al. 2004). Geochemical analyses including the amount of oxides, percentage of loss on ignition material, major and trace elements were measured then XRF method at the Hesgar Mavad Saba Laboratory (HMS) in Iran. Multivariate statistical tools including correlation coefficient, cluster analysis, and principal component analysis (PCA) were determined using PAST software (Hammer et al. 2001). Historical evidence was analysed using the data from historical-geographical sources including historical books, reports, and itineraries of different historical periods through analytical-explanatory techniques.

\section{RESULTS}

\section{CHRONOLOGY}

The results of the $14 \mathrm{C}$ dating are presented in Tab. 1 and Fig. 5. The ages were calibrated using OxCal 4.3.1 software (Ramsey \& Lee 2013), sum of data and atmospheric curve IntCal13 (Reimer et al. 2013), for the Gh1 sample, which showed high levels of radiocarbon activity (pMC), annexed curves of Post-Bomb04NH2. ${ }^{14} \mathrm{C}$ and PostBomb13NH2.${ }^{14} \mathrm{C}$ (Hua \& Barbetti 2004; Hua et al. 2013) were also integrated.

\section{AGE-DEPTH MODELLING}

The three dates were used to establish an age-depth model, based on linear interpolation between all ages of ${ }^{14} \mathrm{C}$ using the latest version of Bacon 2.2 software (Blaauw 2010) applied in environmental $\mathrm{R}$ and R-Studio software (R Development Core Team 2013) (Fig. 5). According to age-depth model, using three ages of ${ }^{14} \mathrm{C}$, guano layers have been deposited for 4060 years till now in the Kolatarika Cave.

\section{GEOCHEMICAL DATA AND STATISTICAL STUDIES}

The results of geochemistry (Figs. 6 and 7) show that the guano composition consists of $\mathrm{SiO}_{2}, \mathrm{Al}_{2} \mathrm{O}_{3}, \mathrm{Fe}_{2} \mathrm{O}_{3}, \mathrm{CaO}$, $\mathrm{Na}_{2} \mathrm{O}, \mathrm{MgO}, \mathrm{K}_{2} \mathrm{O}, \mathrm{TiO}_{2}, \mathrm{MnO}, \mathrm{P}_{2} \mathrm{O}_{5}$ oxides, and $\mathrm{Cl}, \mathrm{S}, \mathrm{As}$, $\mathrm{Ba}, \mathrm{Ce}, \mathrm{Co}, \mathrm{Cr}, \mathrm{Cu}, \mathrm{Nb}, \mathrm{Ni}, \mathrm{Pb}, \mathrm{Rb}, \mathrm{Sr}, \mathrm{V}, \mathrm{Y}, \mathrm{Zr}, \mathrm{Zn}, \mathrm{Mo}$ elements. The amount of LOI was also measured and is shown in percentages. Correlation results show that there is a significant positive correlation between the amount of LOI with $\mathrm{Na}_{2} \mathrm{O}\left(\mathrm{r}^{2}=0.5\right), \mathrm{MgO}\left(\mathrm{r}^{2}=0.72\right), \mathrm{K}_{2} \mathrm{O}\left(\mathrm{r}^{2}=0.43\right)$, $\mathrm{MnO}\left(\mathrm{r}^{2}=0.63\right)$ oxides and elements of $\mathrm{Cl}\left(\mathrm{r}^{2}=0.75\right)$, As $\left(r^{2}=0.63\right), \mathrm{Pb}\left(r^{2}=0.64\right), \mathrm{Zn}\left(r^{2}=0.4\right)$. The results of dendrogram cluster analysis for guano layers show that these oxides and elements are in the same group as LOI (Fig. 6). The results of analysis of main components (Fig. 7), along with the drawing of a scree plot, which contains about $29.99 \%$ of the information related to number one main component in guano layers (Fig. 8), and plotting the graph of the values of specific vectors of oxides, ele- 


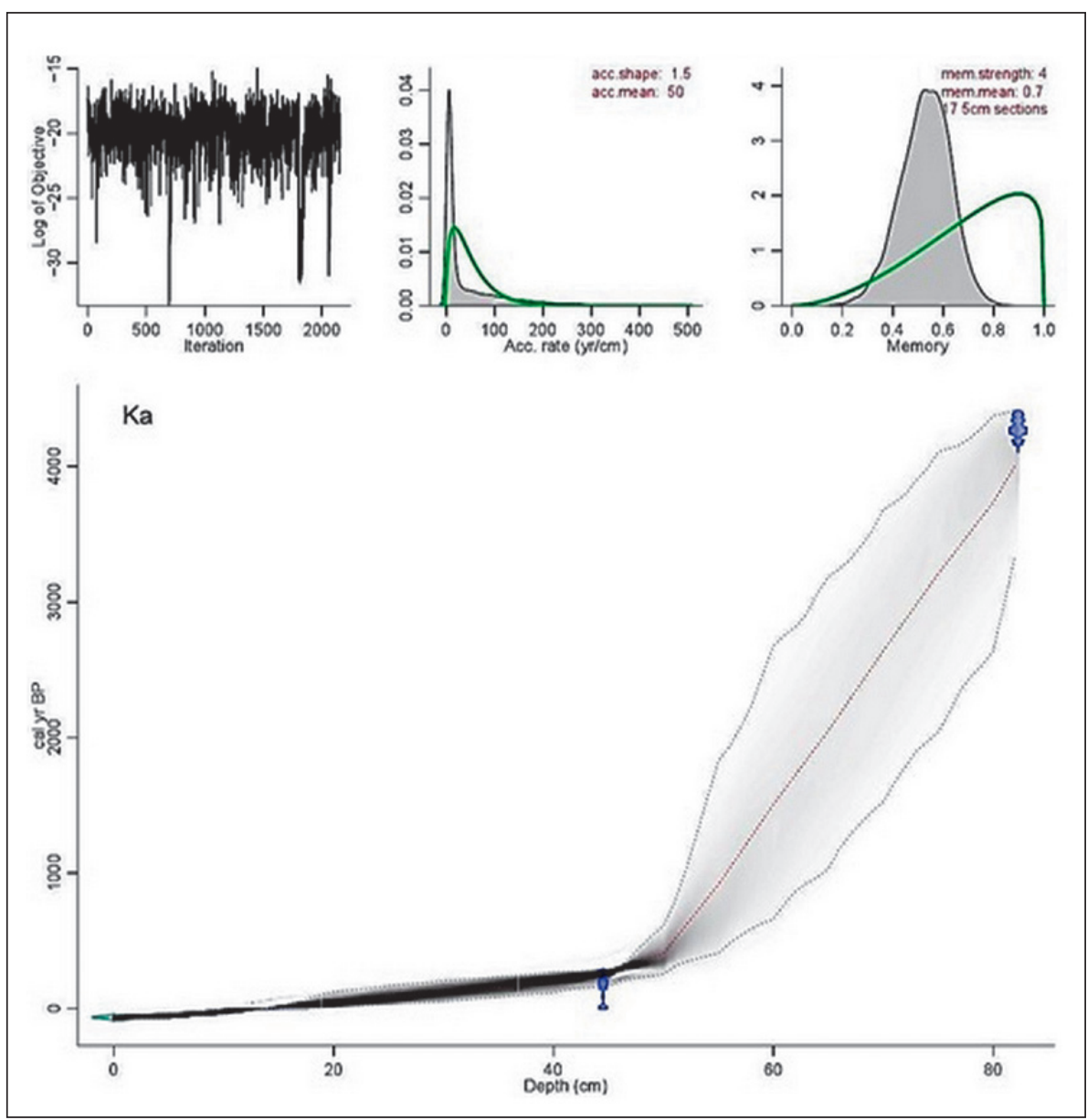

Fig. 5: Age-depth model of ${ }^{14} \mathrm{C}$ age on guano layers of the Kolatarika Cave.

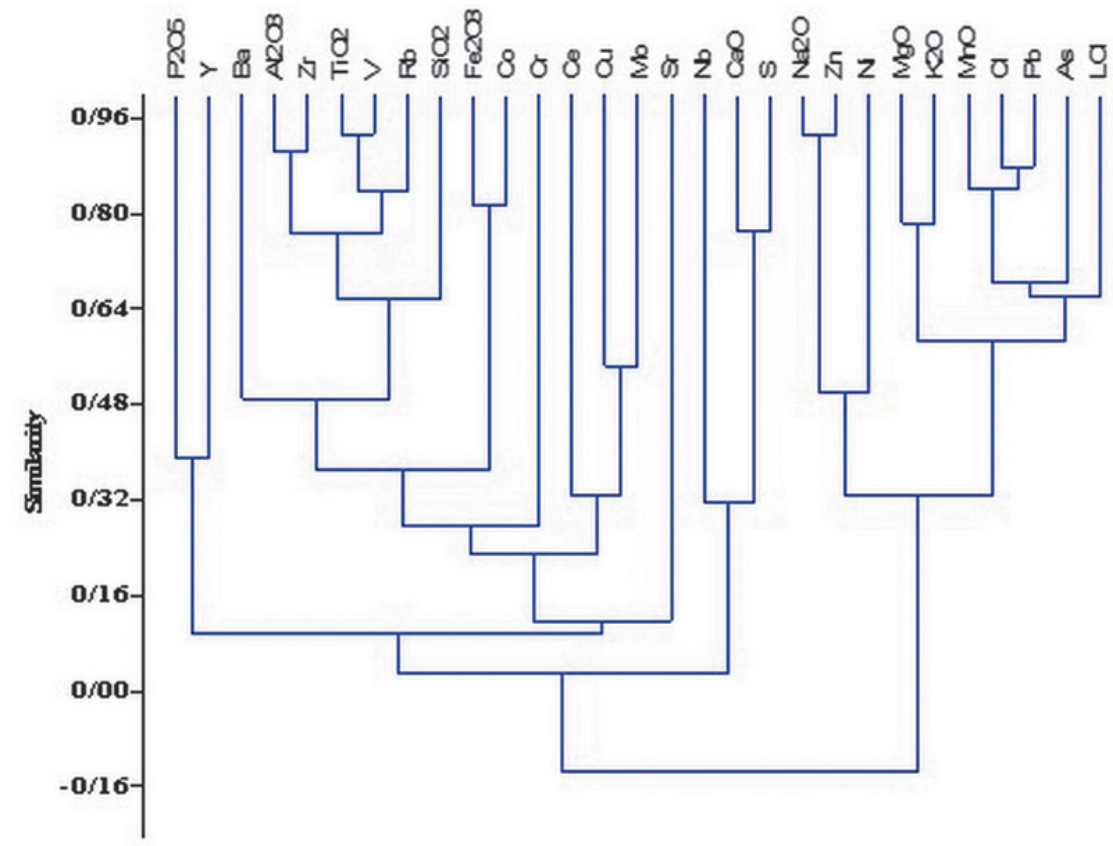

Fig. 6: Dendrogram cluster analysis for oxides, elements, and LOI in guano layers of the Kolatarika Cave. 


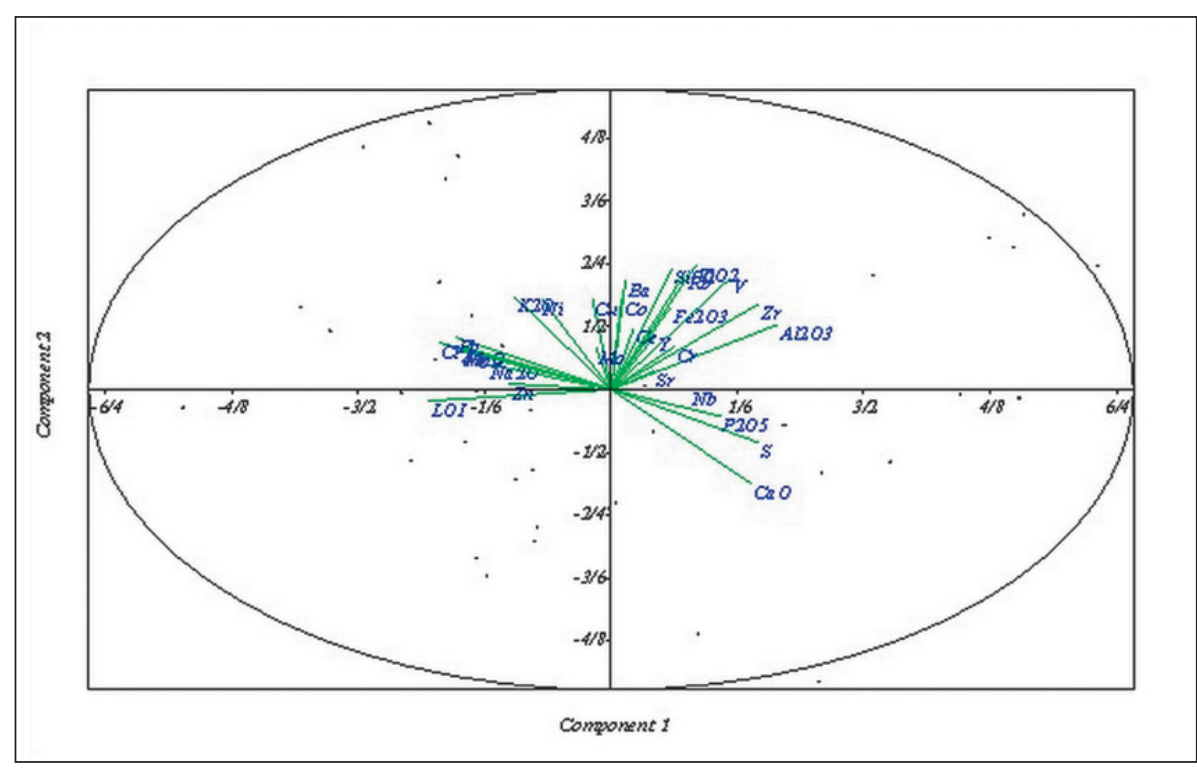

Fig. 7: The chart of analysis for main components of oxides, elements and LOI in guano layers of the Kolatarika Cave.

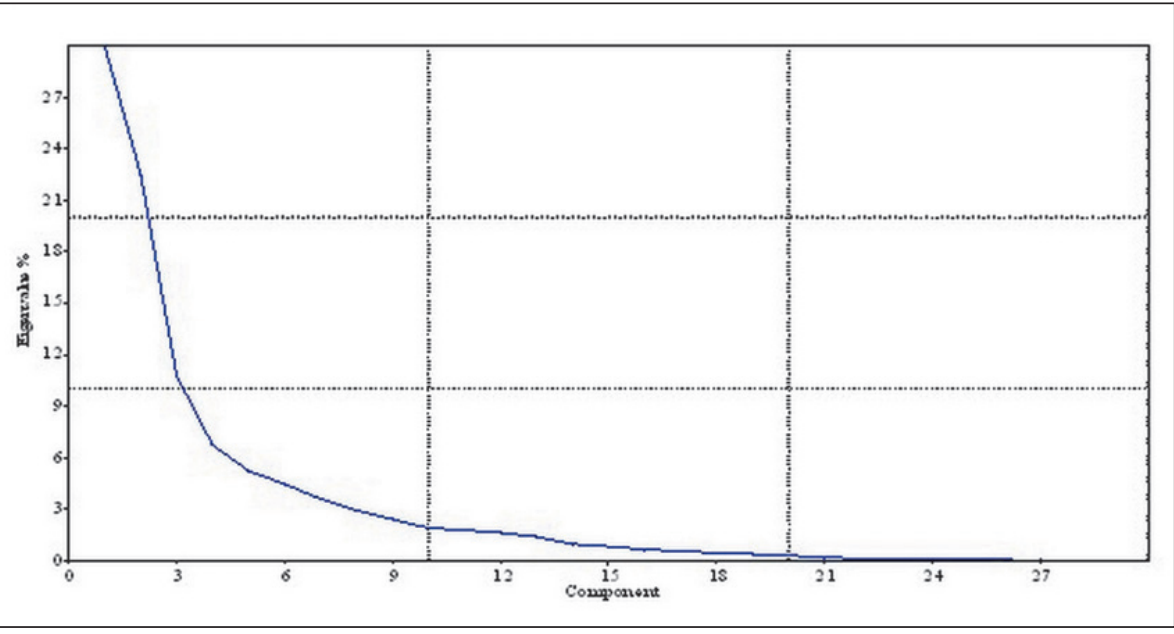

Fig. 8: Scree plot for guano layers in the Kolatarika Cave.

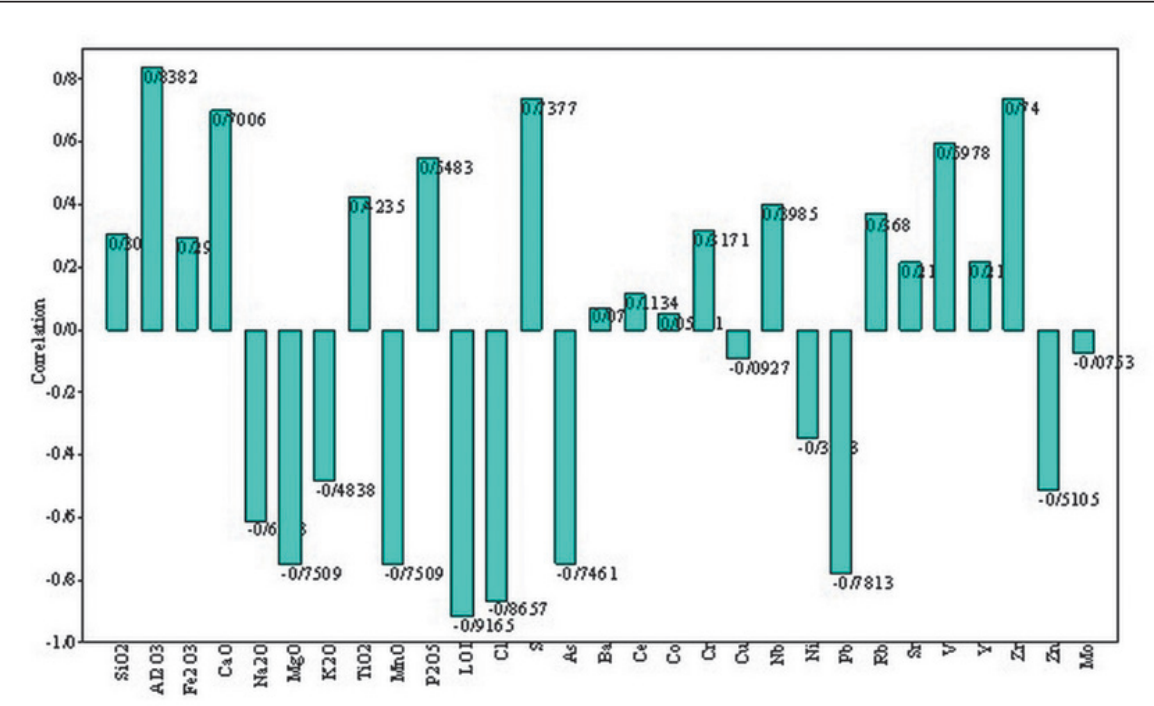

Fig. 9: Presentation chart of values of specific vectors for oxides, elements, and LOI in guano layers of the Kolatarika Cave. 
ments, and LOI in number one main component in guano layers shows that the mentioned elements and oxides have negative weights (load) and are consistent with the results of dendrogram cluster analysis (Fig. 9). Therefore, all these results indicate that these elements and oxides originate from the same source; it is likely they are biological elements and have originated from guano, and according to Dauwe et al. (2000), most of other elements originally belong to guano. These elements include nutritious minerals such as phosphorus $(\mathrm{P})$ and potassium (K). Although, these elements exist in small amounts in the host rock of the cave, but transition metals in certain conditions are adequately repelled by most organisms. Also, nutrients are eliminated by organisms beyond the amount required for metabolism, so many of these elements follow a process like still elements and far exceed the natural abundance of guano. It indicates that these elements are biological elements and originated from guano bats. Therefore, for the interpretation of palaeoclimate, these elements and oxides have been used with LOI.

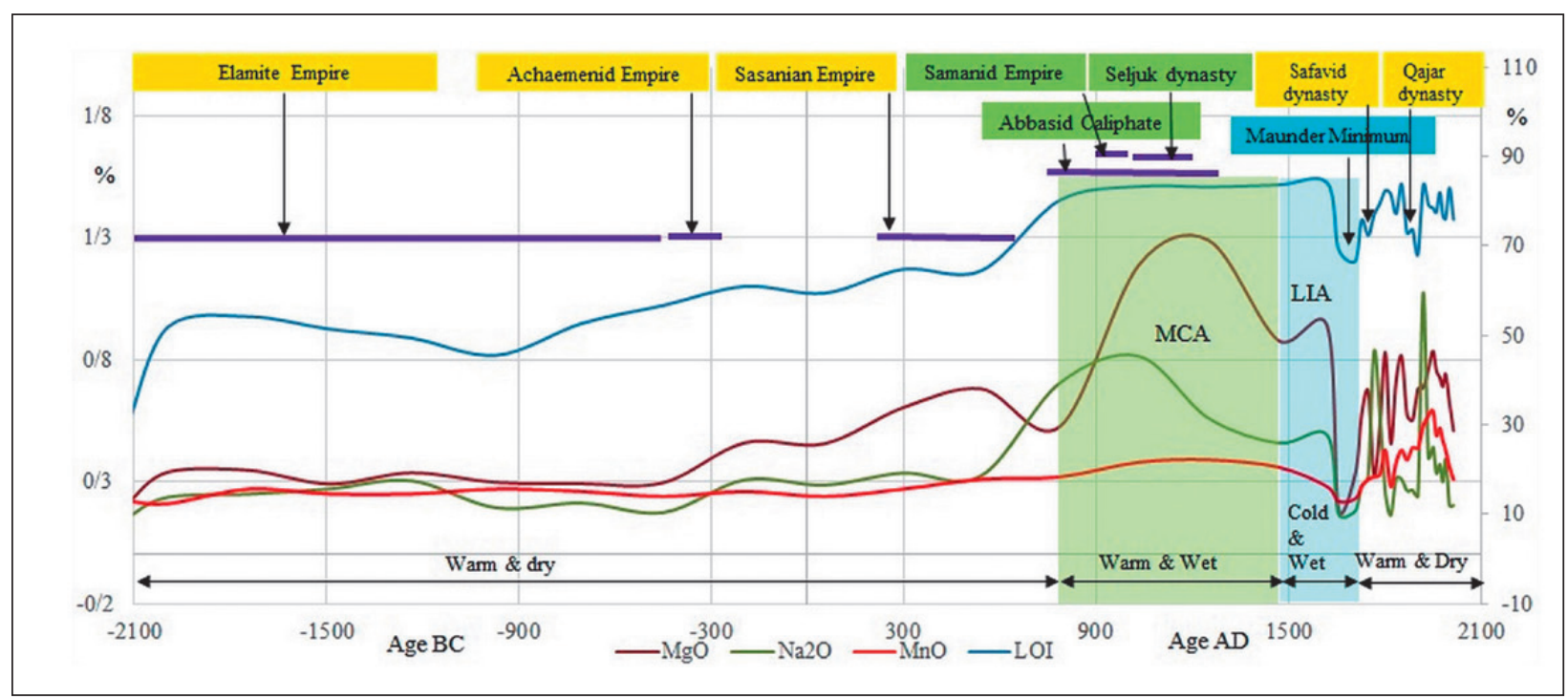

Fig. 10: Comparison of changes in the amount of LOI, $\mathrm{MgO}, \mathrm{Na}_{2} \mathrm{O}$, and $\mathrm{MnO}$ in guano layers of the Kolatarika Cave, time periods of empires and dominant dynasties in Iran and climate changes during the Late Holocene, Meghalaya Stage (Little Ice Age, Medieval Climate Anomaly).

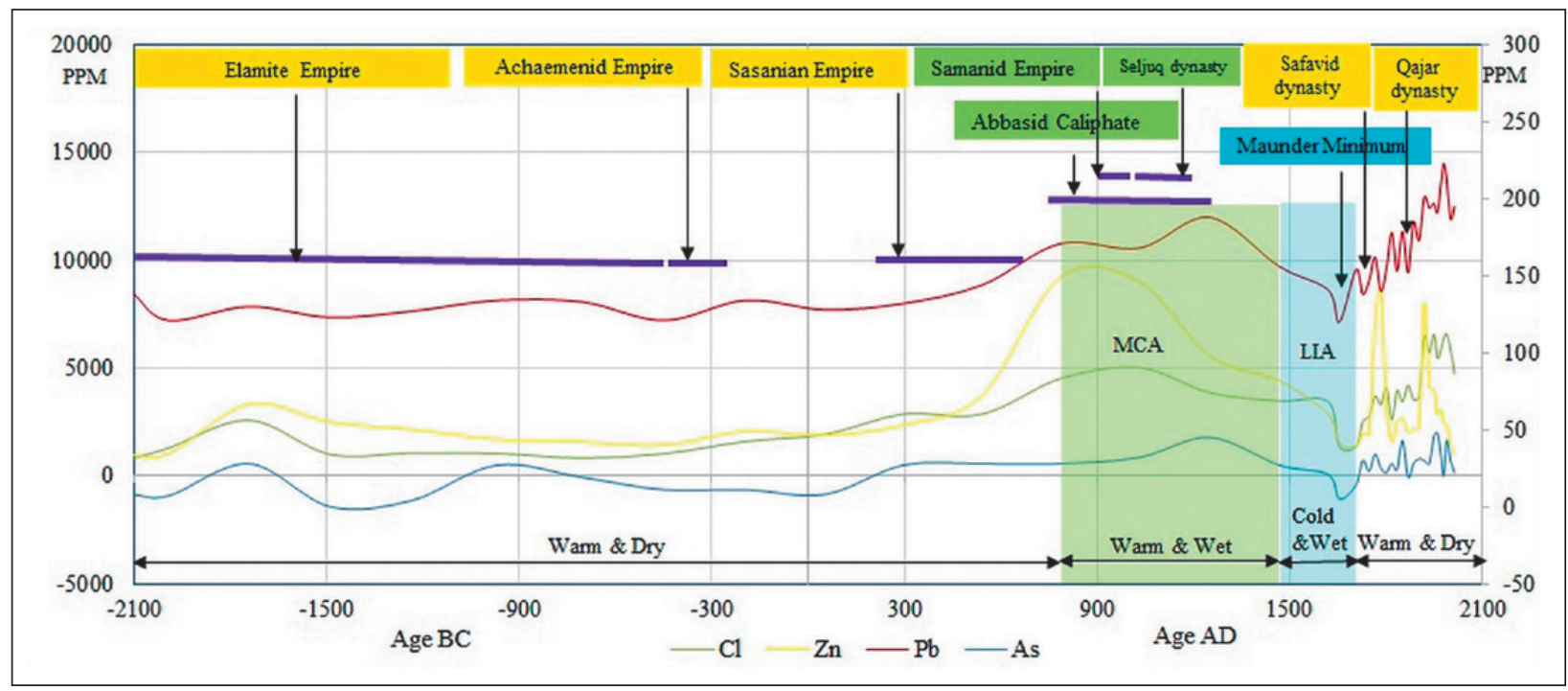

Fig. 11: Comparison of changes in the amount of $\mathrm{Cl}, \mathrm{Zn}, \mathrm{Pb}$, As elements in guano layers of the Kolatarika Cave, time periods of empires and dominant dynasties in Iran during the late Holocene, and dominant climate changes during the Late Holocene, Meghalayan Stage (Little Ice Age, Medieval Climate Anomaly). 
INTERPRETATION OF PALAEOCLIMATE USING HISTORICAL AND ENVIRONMENTAL EVIDENCE

1) The warm and dry conditions (2100 BC - $800 \mathrm{AD})$ coinciding with the Achaemenid period (550-350 BC) and the Sassanid period (224-651 AD)

In this climatic period, in terms of LOI level, the oxides and major and trace elements with biological origin $\left(\mathrm{Na}_{2} \mathrm{O}, \mathrm{MgO}, \mathrm{K}_{2} \mathrm{O}, \mathrm{MnO}, \mathrm{Cl}, \mathrm{As}, \mathrm{Pb}, \mathrm{Zn}\right)$ were minimal (Figs. 7 and 8). The bats of the study region are from Rhinolophidae and Rhinolophus Mehely species and their food includes insect and mainly Lepidoptera and herbal material (Sharifi \& Hemmati 2004). There is a very strong relationship between the prevailing climate conditions, the growth and the number of bat accumulation regarding the density and frequency of insects as food (Hoying \& Kunz 1998; Hood et al. 2002). Therefore, based on the decrease in the amount of LOI and biological elements, it is likely that during this period, the hot and dry climate conditions were dominant (Figs. 10 and 11) which reduced the amount of food, and then it caused the reduction of insects and concentration of bats in the cave.

This warm and dry period was contemporaneous with several historic events such as the excavation of several hundred Qanat during Achaemenid period (330-550 BC) to fight drought (Sharp, 2009), the article by Xenophon based on the fall of Euphrates (401 $\mathrm{BC})$ due to the drought of the Euphrates and its adjacent regions (Ahmadi 2008). Also, constant famine and droughts during the Sassanid period (224-651 $\mathrm{AD}$ ), and extensive use of subterranean canals (Qanat), dams (such as Shadrawan Dam or Qaysar Dam), and water mills were all invented in order to overcome the drought (Al-Muqaddasi 1982; Al-Tabari 1996; Lambton 1996) (Figs. 10 and 11).

Dry climate conditions during this period are also indicated by other climate archives. In the Urmia Lake record pollen proxies indicate steppe vegetation without trees and low levels of water, pointing at a dry climate 1500-2550 years ago (Talebi et al. 2016). More dry and dusty condition were dominant during the late Holocene in Neor Lake, as shown by $\mathrm{Al}, \mathrm{Zr}$, Ti and $\mathrm{Si}$ elements (Sharifi et al. 2015). In Qazvin Plain record geological, geomorphic, and chronological evidence indicate drought peak 4550 years ago during the gap of settlements (Schmidt et al. 2011). The warmer temperatures were dominant between 4 and 5.3 thousand years ago in Zeribar Lake as shown by $\delta^{13} \mathrm{C}$ and $\delta^{18} \mathrm{O}$ (Stevens et al. 2001). Also water level decreased about 3800-4500 years ago in Zeribar Lake as shown by palynological investigations (van Zeist \& Bottema 1977). In Khuzestan plain presence of very dry conditions 5500 years ago led to a decrease in sea level rise (Heyvaert \& Baeteman 2007). In Persian Gulf sea retreated in most of the maritime terrace after 5000 years (Bruthans et al. 2006). In eastern part of Iran the presence of drought conditions have occurred during the middle of Holocene (Walker \& Fattahi 2011).

2) The warm and humid conditions (ca 800-1450 AD), contemporaneous with Medieval Climate Anomaly (MCA) or the Medieval Warm Period (MWP), contemporaneous with the Samanid dynasties (892999 AD), Seljuk era (1038-1194 AD) and the Abbasid Caliphate (750-1258 AD) in Iran

The warm period of Medieval Climate, Medieval Climate Anomaly and Medieval Climate Optimum in the northern Atlantic which may be associated with other climate events at that time lasted from around $950 \mathrm{AD}$ to $1250 \mathrm{AD}$ (Mann et al. 2009) and was along with colder period of Little Ice Age after that. Some experts have emphasized the importance of higher temperature effects (Bradley et al. 2003) in Medieval Climate Anomaly.

Regarding the amounts of LOI, oxides, main and secondary elements with biological origin $\left(\mathrm{Na}_{2} \mathrm{O}, \mathrm{MgO}\right.$, $\mathrm{K}_{2} \mathrm{O}, \mathrm{MnO}, \mathrm{Cl}, \mathrm{As}, \mathrm{Pb}, \mathrm{Zn}$ ), this period has the highest rates compared to the previous and next periods. The reason (Figs. 10 and 11) is that warmer climate conditions and moderate precipitation increase the frequency of insects (Williams 1961; Taylor 1963). Increasing food income would increase the production of milk by mothers and the growth rate of new-borns. These bats have only one reproductive season per year (Tuttle \& Stevenson 1982). Their delivery and lactation cycles correspond to the maximum available food in summer (Barclay \& Harder 2003). Young bats should also store fat deposits immediately before the start of first winter season (Tuttle \& Stevenson 1982). Therefore, due to the highest amount of LOI and other biological elements in this time period, the probability of having warm and humid climate conditions was higher in the region (Figs. 10 and 11), which caused the increase of insects' frequency, herbaceous materials and providing favourable conditions for physiological growth and number of bat accumulation in the cave during this period compared to periods before and after that. Synchronically, these warm and humid conditions with historical events, almost all sources of the Samanid period (892-999 AD) refer to the abundance of natural blessings in their territory which was due to the existence of moisture and heavy rainfall. Istakhri (also Estakhri) (1995) has considered the Samanid territory as the area that had the most blessings. In the circle of Islam, it was mentioned that in all territories, famine could be seen but here it was less. Cities sprinkled with springs and 
rain water found throughout this ice and snow area (Ibn Hawqal 1966) is another sign. Al-Muqaddasi (1982) has referred to the abundance of water and its lightness and sanity. Also, sources of Seljuk period (1094-1194 AD) indicated that river flow and irrigation of all farms and villages of Isfahan by Zayande-Rud River refers to the existence of humid weather (Ibn Hawqal 1966). Producing and exporting a variety of products such as saffron (Al-Hamawi 1979), cultivation of cereals, grains and rice (Al-Karaji 1945), the presence of many grasslands (Khusraw 2003) and the populous cities during the Seljuk period (Pigolevskaia 1975) were related to humid climate conditions in this period (Figs. 10 and 11).

During the Abbasid Caliphate (750-1258), Muslims paid much attention to agriculture and built a network of irrigation, dam and different bridges and they started agriculture between Tigris and Euphrates. During this period, gardens and trees increased and the region of "Arze Sawad" appeared which spread from Mosul to Abadan, from Al-Qadisiyyah to Hulwan and Sarpol-e Zahab, with an area of over three hundred and sixty million acres (Hassan 1953). Increase in rainfall, flooding of Tigris and Euphrates, flooding and submerge of Baghdad agricultural lands between 232 and $656 \mathrm{AH}$ (256-846 AD) probably were due to economic degeneration of Baghdad in the era of Abbasid Caliphate (Ibn Kathir 1998; Al-Fuwati 2002). It was related to warm and humid climate conditions (Figs. 11 and 12).

Hot and humid climate conditions during this period are also indicated by other climate archives, in cluding: rise of Caspian Sea water level between 750 $1150 \mathrm{AD}$ due to the presence of a humid phase (Ramezani et al. 2016), occurrence of a wet phase without dust between years 800-1350 AD between the two dry and dust-rich phases of 650-800 and 1350-1500 AD in Almalou Lake (Sharifi et al. 2013), prevalence of humid climate conditions between 1000-1350 BC in the northern slopes of the middle Alborz (Ramezani et al. 2008), the beginning of the maximum of humidity conditions about 3000 years ago and reaching its maximum level in Medieval Climate Anomaly one thousand years ago (Fallah et al. 2017), domination of warm and dry climate conditions during 800-1100 years ago in Urmia Lake (Talebi et al. 2016), descending Caspian Sea level due to the occurrence of a dry phase between 500-1300 AD (Kakroodi et al. 2012; 2015), domination of dry conditions from 900-1450 in Oman Gulf (Miller et al. 2016), downfall level of Caspian Sea to the range of 28 metres due to the existence of dry phase between 10001250 AD (Beni et al. 2013), and domination of hot and dry phase between 800-1400 AD on Neor Lake (Sharifi et al. 2015).
Domination of warm and humid climate during this period is consistent with other obtained results from palaeoclimate conditions of West, Southwest Asia, including: existence of a humid phase of 900$1400 \mathrm{AD}$ in Nar Lake of Turkey (Dean et al. 2015), more humid climate conditions in years 1000-1250 AD in Syria (Kaniewski et al. 2011), humid climate conditions from 1000-1300 AD along with the raise of water level in Dead Sea (Migowski et al. 2006), the humid phase of 700-1600 AD in Dead Sea (Litt et al. 2012), a humid period between 1400-1430 AD in Syria (Kaniewski et al. 2011), warm and humid periods between 1000-1250 AD in Syria (Kaniewski et al. 2011), humid phase between 1000-1200 AD in Tecer Lake of Turkey (Kuzucuoğlu et al. 2011), humid phase of 9501400 AD in Nar Lake of Turkey (Woodbridge \& Roberts 2011), humid periods between 800-1350 AD in Çubuk Lake of Turkey (Ocakoğlu et al. 2016), humid periods between 1000-1200 AD in the Black Sea coast of Turkey (Mertens et al. 2012), humid periods between 1000-1400 in Black Sea of Turkey (Lamy et al. 2006), hot and humid period between 700-1150 years ago in Iznik Lake of Turkey (Ülgen et al. 2012), humid conditions between 700-1400 AD in Larnaca Salt Lake in Cyprus (Kaniewski et al. 2013), and humid phase during Medieval Climate Anomaly period between 700-1300 $\mathrm{AD}$ on the shores of Black Sea in Georgia (de Klerk et al. 2009), and results from palaeoclimate conditions of Greenland, including: existence of a temperature of +1 degree Celsius during Medieval Climate Anomaly period between 700-1200 AD compared to Little Ice Age in Greenland GRIP3Dye (Dahl-Jensen et al. 1998), presence of a concentrated warm phase around $1000 \mathrm{AD}$ in Greenland 2 GISP, Dye, Camp Century, Renland, GRIP3NGRIP (Johnsen et al. 2001; Andresen et al. 2004), mild warming between 900 and 1400 years ago along with Medieval Climate Anomaly in Disko Bugt Greenland (Perner et al. 2013).

3) The cold and humid conditions (1600-1750 AD) along with the Little Ice Age and Maunder Minimum and warm and dry conditions in Late Holocene, Meghalayan Stage, along with the Safavid and the Qajar dynasties in Iran

Little Ice Age is defined as an extended period from $16^{\text {th }}$ century to $19^{\text {th }}$ century. But some experts prefer to replace a period of time from about $1300 \mathrm{AD}$ to 1850 (Miller, 2012).

In this climate period, the amount of LOI, oxides, main and secondary elements of biological origin $\left(\mathrm{Na}_{2} \mathrm{O}, \mathrm{MgO}, \mathrm{K}_{2} \mathrm{O}, \mathrm{MnO}, \mathrm{Cl}, \mathrm{As}, \mathrm{Pb}, \mathrm{Zn}\right)$ had decreased compared to the previous period, namely Medieval Climate Anomaly (Figs. 10 and 11). Since the available 
food is expressed in terms of frequency of insects, it changes significantly as a function of climate from one year to the next (Williams 1961).

For example, lower temperature and heavy rainfalls decrease the frequency of insects (Taylor 1963). Furthermore, Hoying and Kunz (1998) indicate that significant decrease would be observed in the growth of bats in postnatal stage in summers with a relatively cooler degree of temperature and higher precipitation. In addition, extreme climate conditions can increase the use of hibernation in female pregnant and lactating bats (Hoying \& Kunz 1998). Also, hibernation reduces the metabolism and processes associated with the preservation of a growing fetus and milk production (Wilde et al. 1995), thus it leads to the reduction of birth rate in bats. Hood et al. (2002) indicated that by the increase of precipitation in the month before birth, body mass and length of forearm in bats was the least at the time of birth. Furthermore, by a decline of temperature in the surrounding environment during the late stages of pregnancy, body mass of bats at birth time was significantly little. Therefore, it is likely that during this period the region had a cool and humid climate (Figs. 10 and 11). This decrease in temperature and air cooling and increased moisture content reduced food (the frequency of insects) and birth rate and caused changes in the physiological characteristics of bats. As a result, the accumulation of bats in the cave dropped dramatically compared to Medieval Climate Anomaly period. These results, namely cold and humid climate during Little Ice Age is consistent with other obtained results in palaeoclimate of Iran including: rise of Caspian Sea surface in the northern slopes of middle Alborz due to the presence of cold and humid climate during Little Ice Age (Ramezani et al. 2008), a rise in water level of Caspian Sea to 44.21 metres (up to 6 metres above the present water level) at the beginning of the Little Ice Age (Haghani et al. 2016), the last occurrence of upraise in Caspian Sea water for 504-615 and 556-670 years ago (Kakroodi et al. 2012; 2015), domination of more humid conditions in Oman Gulf during Little Ice Age (Miller et al. 2016), occurrence of last major rise 2600 years ago and During Little Ice Age in the Caspian Sea (Kroonenberg et al. 2007), dominance of cold and humid climate and the rise of Caspian Sea water during Little Ice Age from 1650 to 1800-1830 in Anzali and Amirkola Lagoons (Leroy et al. 2011), higher levels of Almalou Lake water as a result of low summer temperatures or high levels of annual rainfall during the Little
Ice Age (Djamali et al. 2009), upraise of Caspian Sea water up to 21 metres during Little Ice Age (Beni et al. 2013), occurrence of Little Ice Age between 1560-1660 at the northern slopes of middle Alborz (Ramezani et al. 2008), and increase in water surface of Urmia Lake due to cold and dry weather during $150-550$ years ago (Talebi et al. 2016).

Cold and humid climate conditions during Little Ice Age in West and Southwest Asia are also indicated by other climate archives, including: existence of a humid phase in 1050-1150, a dry phase in 1150-1250 and a humid phase in 1250-1400 AD in the Gejkar Cave in the north of Iraq (Flohr et al. 2017), dominance of more humid climate during Little Ice Age in Hoti Cave and Oman (Fleitmann et al. 2007; 2009), and results of palaeoclimate in Greenland including: reduction of temperature about 0.5 to 0.7 Kelvin degrees during Little Ice Age compared to the present time in Greenland Dye 3 GRIP (Dahl-Jensen et al. 1998), a distinctive sign for Little Ice Age, and a distinctive sign for air warming in recent centuries in Greenland, 2GISP, Dye, Camp Century, Renland, 3 NGRIP, GRIP (Johnsen et al. 2001; Andresen et al. 2004), reaching the maximum level of Neoglacial in Greenland's iceberg area in the late 1880s and beginning of $1900 \mathrm{AD}$ (Funder et al. 2011), progress of ice sheets more than the current level during Little Ice Age in Greenland (Vasskog et al. 2015), existence of cold and humid conditions of Little Ice Age in Tecer Lake of Turkey (Kuzucuoğlu et al. 2011), and humid conditions during Little Ice Age in the Golhisar Lake of Turkey (Eastwood et al. 2007).

Also, this period is consistent with Maunder Minimum period which is known as a long standing period (1645-1715 AD) with minimum amount of sunspots (Eddy 1976) (Figs. 10 and 11).

In terms of historical events, the last part of this period was contemporaneous with decline of agriculture, drying of several aqueducts and water scarcity, water shortage in all parts of Iran (Tavernier 1984), increase of mortality in Tabriz, Ardebil, Isfahan and Qom due to famine and water scarcity (Hosseini Qomi 1984), decline of water and drying up in Zayande-Rud and offering a plan to transfer water of Karun to Isfahan (Sanson 1967) along with the late Safavid period (1501-1722), occurrence of drought, large famine and drying of Zayande-Rud water, decrease in the population of regions in Azerbaijan, Yazd, Khorasan, Khuzestan, Qom, Kermanshah, Isfahan, Shiraz (Okazaki 1986; Curzon 2009; Lambton 1996), during Qajar dynasty (1795-1925) (Figs. 11 and 12). 


\section{CONCLUSION}

The obtained AMS ${ }^{14} \mathrm{C}$ ages from the $86 \mathrm{~cm}$ sequence of bat guano layers in the Kolatarika cave of Kurdistan province in the west of Iran demonstrate that this sequence covers an age of 4060 years. The results of geochemical data, statistical studies, along with the investigation, analysis and explanation of books and historical field trip logs refers to the presence of warm and dry climate conditions between ca $2100 \mathrm{BC}$ and $800 \mathrm{CE}$, which was contemporaneous with the occurrence of periods of drought and famine during the Achaemenid and Sassanid empires. The occurrence of such drought conditions probably was one of the causes of the collapse of these empires in Iran. The existence of humid climate condi- tions between ca 800 and $1450 \mathrm{AD}$ was contemporaneous with the period of Medieval Climate Anomaly, the abundance of prosperity, the prosperity of farms and agriculture during the Seljuk dynasty, the Samanids, and the rise of rainfall and river floods during the period of the $\mathrm{Ab}$ basid Caliphate. The presence of cold and humid climate conditions between ca 1600 and $1750 \mathrm{AD}$ was contemporaneous with a Little Ice Age and Maunder Minimum period. After this period, the climate of this area changed to warm and dry which was contemporaneous with the occurrence of famine and subsequent droughts of the late Safavid and the Qajar dynasties.

\section{ACKNOWLEDGMENTS}

We are grateful to Dr. Pascal Flohr (University of Oxford), Dr. Arash Sharifi (University of Miami) for correcting the English and providing enormous valuable comments and suggestions. Furthermore we wish to thank the Editor and the anonymous reviewers for their relevant comments and detailed suggestions.

\section{REFERENCES}

Ahmadi, A., 2008: The evidences for the prominence of the Goddess Anahita during the reign of Artaxerxes II (358-405 B.C).- The Journal of Epics Literature, 3, 5, 139-148.

Al-Fuwati, I., 2002: Al - Hawadith al - jamia, historical events of the 7th century (translation A. Ayati).- Anjoman Asar-e Meli, pp. 363, Tehran.

Al-Hamawi, Y., 1979: Mugam al-buldân.- Dâr Sâdir, pp. 536, Beirut.

Al-Karajī, A.B.M., 1945: Inbāt al-miyāh al-Khaffiyya (Search for Hidden Waters) (translation H. khadiv Jam).- Astan Quds Razavi, pp. 460, Mashhad.

Al-Muqaddasi, A., 1982: Ahsan al-taqasim fì márifat alaqālim (The best division for the knowledge of the provinces) (translation A.N. Monzavi).- Sherkate Moalefan va Motarjeman, pp. 310, Tehran.

Al-Tabari, I.J., 1996: Tarikh al-Rusul wa al-Muluk (Tarikh al-Tabari) (translation A. Payandeh).- Elmi Farhangi, pp. 366, Tehran.

Andresen, C.S., Björck, S., Bennike, O. \& G. Bond, 2004: Holocene climate changes in southern Greenland: evidence from lake sediments.- Journal of Qua- ternary Science, 19, 8, 783-795. DOI: https://doi. org/10.1002/jqs. 886

Barclay, R.M. \& L.D. Harder, 2003: Life Histories of Bats: Life in the Slow Lane.- In: Kunz, T.H. \& M.B. Fenton (eds.) Bat ecology. The University of Chicago Press, pp. 209-253, Chicago.

Batina, M.C. \& C.A. Reese, 2011: A Holocene pollen record recovered from a guano deposit: Round Spring Cavern, Missouri, USA.- Boreas, 40, 2, 332-341. DOI: https://doi.org/10.1111/j.15023885.2010.00186.x

Beni, A.N., Lahijani, H., Harami, R.M., Arpe, K., Leroy, S.A.G., Marriner, N., Berberian, M., Andrieu-Ponel, V., Djamali, M., Mahboubi, A. \& P.J. Reimer, 2013: Caspian sea-level changes during the last millennium: historical and geological evidences from the south Caspian Sea.- Climate of the Past, 9, 4, 16451665. DOI: https://doi.org/10.5194/cp-9-1645-2013

Blaauw, M., 2010: Methods and code for 'classical' agemodelling of radiocarbon sequences.- Quaternary Geochronology, 5, 5, 512-518. DOI: https://doi. org/10.1016/j.quageo.2010.01.002 
Bradley, R.S., Briffa, K.R., Cole, J., Hughes, M.K. \& T.J. Osborn, 2003: The Climate of the Last Millennium.In: Alverson, K.D., Pedersen, T.F. \& R.S. Bradley (eds.) Paleoclimate, Global Change and the Future. Global Change - The IGBP Series. Springer, pp. 105-141, Berlin. DOI: https://doi.org/10.1007/9783-642-55828-3_6

Bruthans, J., Filippi, M., Geršl, M., Zare, M., Melková, J., Pazdur, A. \& P. Bosák, 2006: Holocene marine terraces on two salt diapirs in the Persian Gulf, Iran: age, depositional history and uplift rates.- Journal of Quaternary Science, 21, 8, 843-857. DOI: https:// doi.org/10.1002/jqs.1007

Campbell, J.W., Waters, M.N. \& F. Rich, 2017: Guano core evidence of palaeoenvironmental change and Woodland Indian inhabitance in Fern Cave, Alabama, USA, from the mid-Holocene to present.- Boreas, 46, 3, 462-469. DOI: https://doi.org/10.1111/ bor. 12228

Curzon, J., 2009: Iran wa Qaziych Iran (Persia and the Persian Question) (translation G.V. Mazandarani).Elmi Farhangi, pp. 824, Tehran.

Dahl-Jensen, D., Mosegaard, K., Gundestrup, N., Clow, G.D., Johnsen, S.J., Hansen, A.W. \& N. Balling, 1998: Past temperatures directly from the Greenland ice sheet.- Science, 282, 5387, 268-271. DOI: https://doi.org/10.1126/science.282.5387.268

Dauwe, T., Bervoets, L., Blust, R., Pinxten, R. \& M. Eens, 2000: Can excrement and feathers of nestling songbirds be used as biomonitors for heavy metal pollution?.- Archives of Environmental Contamination and Toxicology, 39, 4, 541-546. DOI: https://doi. org/10.1007/s002440010138

de Klerk, P., Haberl, A., Kaffke, A., Krebs, M., Matchutadze, I., Minke, M., Schulz, J. \& H. Joosten, 2009: Vegetation history and environmental development since ca $6000 \mathrm{cal} \mathrm{yr} \mathrm{BP}$ in and around Ispani 2 (Kolkheti lowlands, Georgia).- Quaternary Science Reviews, 28, 9-10, 890-910.

Dean, J.R., Jones, M.D., Leng, M.J., Noble, S.R., Metcalfe, S.E., Sloane, H.J., Sahy, D., Eastwood, W.J. \& C.N. Roberts, 2015: Eastern Mediterranean hydroclimate over the late glacial and Holocene, reconstructed from the sediments of Nar lake, central Turkey, using stable isotopes and carbonate mineralogy.Quaternary Science Reviews, 124, 162-174. DOI: https://doi.org/10.1016/j.quascirev.2015.07.023

DeMenocal, P.B., 2001: Cultural responses to climate change during the late Holocene.- Science, 292, 5517, 667-673. DOI: www.jstor.org/stable/3083536

Djamali, M., de Beaulieu, J.-L., Andrieu-Ponel, V., Berberian, M., Miller, N.F., Gandouin, E., Lahijani, H., Shah-Hosseini, M., Ponel, P., Salimian, M. \& F. Guit- er, 2009: A late Holocene pollen record from Lake Almalou in NW Iran: evidence for changing landuse in relation to some historical events during the last 3700 years.- Journal of Archaeological Science, 36, 7, 1364-1375. DOI: https://doi.org/10.1016/j. jas.2009.01.022

Eastwood, W.J., Leng, M.J., Roberts, N. \& B. Davis, 2007: Holocene climate change in the eastern Mediterranean region: a comparison of stable isotope and pollen data from Lake Gölhisar, southwest Turkey.Journal of Quaternary Science, 22, 4, 327-341. DOI: https://doi.org/10.1002/jqs.1062

Eddy, J.A., 1976: The Maunder Minimum.- Science, 192, 4245, 1189-1202. DOI: https://doi.org/10.1126/science.192.4245.1189

Estakhri, A.A., 1995: Masalek \& mamalek.- Bungāh-i Tarjumah va Nashr-i Kitāb, pp. 334, Tehran.

Fallah, B., Sodoudi, S., Russo, E., Kirchner, I. \& U. Cubasch, 2017: Towards modeling the regional rainfall changes over Iran due to the climate forcing of the past 6000 years.- Quaternary International, 429, Part B, 119-128. DOI: https://doi.org/10.1016/j. quaint.2015.09.061

Fleitmann, D., Burns, S.J., Mangini, A., Mudelsee, M., Kramers, J., Villa, I., Neff, U., Al-Subbary, A.A., Buettner, A., Hippler, D. \& A. Matter, 2007: Holocene ITCZ and Indian monsoon dynamics recorded in stalagmites from Oman and Yemen (Socotra).Quaternary Science Reviews, 26, 1-2, 170-188. DOI: https://doi.org/10.1016/j.quascirev.2006.04.012

Fleitmann, D., Cheng, H., Badertscher, S., Edwards, R.L., Mudelsee, M., Göktürk, O.M., Fankhauser, A., Pickering, R., Raible, C.C., Matter, A., Kramers, J. \& O. Tüysüz, 2009: Timing and climatic impact of Greenland interstadials recorded in stalagmites from northern Turkey.- Geophysical Research Letters, 36, 19, 1-5. DOI: https://doi. org/10.1029/2009GL040050

Flohr, P., Fleitmann, D., Zorita, E., Sadekov, A., Cheng, H., Bosomworth, M., Edwards, L., Matthews, W. \& R. Matthews, 2017: Late Holocene droughts in the Fertile Crescent recorded in a speleothem from northern Iraq.- Geophysical Research Letters, 44, 3, 15281536. DOI: https://doi.org/10.1002/2016GL071786

Forray, F.L., Onac, B.P., Tanţău, I., Wynn, J.G., Tămaş, T., Coroiu, I. \& A.M. Giurgiu, 2015: A Late Holocene environmental history of a bat guano deposit from Romania: an isotopic, pollen and microcharcoal study.- Quaternary Science Reviews, 127, 141-154. DOI: https://doi.org/10.1016/j.quascirev.2015.05.022

Founoudi, M., Hariri, A. \& A.R. Babakhani, 1998: Geological map of Takab, 1:100 000.- Iran. 
Funder, S., Kjeldsen, K.K., Kjær, K.H. \& C.O. Cofaigh, 2011: Chapter 50 - The Greenland Ice Sheet during the past 300,000 years: A review.- Developments in Quaternary Sciences, 15, 699-713. DOI: https://doi. org/10.1016/B978-0-444-53447-7.00050-7

Geantă, A., Tanţău, I., Tămaş, T. \& V.E. Johnston, 2012: Palaeoenvironmental information from the palynology of an 800 year old bat guano deposit from Măgurici Cave, NW Transylvania (Romania).- Review of Palaeobotany and Palynology, 174, 57-66. DOI: https://doi.org/10.1016/j.revpalbo.2011.12.009

Goslar, T., Czernik, J. \& E. Goslar, 2004: Low-energy ${ }^{14} \mathrm{C}$ AMS in Poznań Radiocarbon Laboratory, Poland.- Nuclear Instruments and Methods in Physics Research Section B: Beam Interactions with Materials and Atoms, 223-224, 5-11. DOI: https://doi. org/10.1016/j.nimb.2004.04.005

Haghani, S., Leroy, S.A., Khdir, S., Kabiri, K., Naderi Beni, A. \& H.A.K. Lahijani, 2016: An early 'Little Ice Age'brackish water invasion along the south coast of the Caspian Sea (sediment of Langarud wetland) and its wider impacts on environment and people.- The Holocene, 26, 1, 3-16. DOI: https://doi. org/10.1177/0959683615596835

Hammer, Ø., Harper, D.A.T. \& P.D. Ryan, 2001: Paleontological statistics software: package for education and data analysis.- Palaeontologia Electronica, 4, 1, $1-9$.

Hassan, I.H., 1953: Thareekhi Syasi Islam (translation A. Payandeh).- Javidan Publication, pp. 1076, Tehran.

Heyvaert, V.M.A. \& C. Baeteman, 2007: Holocene sedimentary evolution and palaeocoastlines of the Lower Khuzestan plain (southwest Iran).- Marine Geology, 242, 1-3, 83-108. DOI: https://doi. org/10.1016/j.margeo.2007.01.008

Hood, W.R., Bloss, J. \& T.H. Kunz, 2002: Intrinsic and extrinsic sources of variation in size at birth and rates of postnatal growth in the big brown bat Eptesicus fuscus (Chiroptera: Vespertilionidae).- Journal of Zoology, 258, 3, 355-363. DOI: https://doi. org/10.1017/S0952836902001504

Hosseini Qomi, Q.A., 1984: Kholase al tavarikh (correction by Ehsan Eshraqi).- Tehran University Publication, pp. 614, Tehran.

Hoying, K.M. \& T.H. Kunz, 1998: Variation in size at birth and post-natal growth in the insectivorous bat Pipistrellus subflavus (Chiroptera: Vespertilionidae).- Journal of Zoology, 245, 1, 15-27. DOI: https://doi.org/10.1111/j.1469-7998.1998.tb00067.x

Hua, Q. \& M. Barbetti, 2004: Review of tropospheric bomb ${ }^{14} \mathrm{C}$ data for carbon cycle modeling and age cal- ibration purposes.- Radiocarbon, 46, 3, 1273-1298. DOI: https://doi.org/10.1017/S0033822200033142

Hua, Q., Barbetti, M. \& A.Z. Rakowski, 2013: Atmospheric radiocarbon for the period 1950-2010.Radiocarbon, 55, 4, 2059-2072. DOI: https:/doi. org/10.2458/azu_js_rc.v55i2.16177

Hutchinson, G.E., 1950: Survey of contemporary knowledge of biogeochemistry. 3. The biogeochemistry of vertebrate excretion.- Bulletin of the American $\mathrm{Mu}$ seum of Natural History, Volume 96, American Museum of Natural History, pp. 554, New York.

Ibn Hawqal, 1966: Iran in Surat al-Ardh (translation Hekmatshoar).- Bonyade Farhange Iran, pp. 377, Tehran.

Ibn-Kathir, A.A.F.I.I., 1998: Al-Bidāyah wa-l-nihāyah.Maktabat al-ma冈ārif, Beirut.

International Union of Geological Sciences, 2018: IUGS, International Commission of Stratigraphy.- [Online] Available from: http://www.iugs.org/ [Accessed 14th July 2018].

Johnsen, S.J., Dahl-Jensen, D., Gundestrup, N., Steffensen, J.P., Clausen, H.B., Miller, H., Masson-Delmotte, V., Sveinbjörnsdottir, A.E. \& J. White, 2001: Oxygen isotope and palaeotemperature records from six Greenland ice-core stations: Camp Century, Dye-3, GRIP, GISP2, Renland and NorthGRIP.- Journal of Quaternary Science, 16, 4, 299-307. DOI: https:// doi.org/10.1002/jqs.622

Johnston, V.E., McDermott, F. \& T. Tămaş, 2010: A radiocarbon dated bat guano deposit from NW Romania: implications for the timing of the Little Ice Age and Medieval Climate Anomaly.- Palaeogeography, Palaeoclimatology, Palaeoecology, 291, 3-4, 217-227. DOI: https://doi.org/10.1016/j.palaeo.2010.02.031

Kakroodi, A.A., Kroonenberg, S.B., Hoogendoorn, R.M., Khani, H.M., Yamani, M., Ghassemi, M.R. \& H.A.K. Lahijani, 2012: Rapid Holocene sea-level changes along the Iranian Caspian coast.- Quaternary International, 263, 93-103. DOI: https:/doi. org/10.1016/j.quaint.2011.12.021

Kakroodi, A.A., Leroy, S.A.G., Kroonenberg, S.B., Lahijani, H.A.K., Alimohammadian, H., Boomer, I. \& A. Goorabi, 2015: Late Pleistocene and Holocene sealevel change and coastal paleoenvironment evolution along the Iranian Caspian shore.- Marine Geology, 361, 111-125. DOI: https://doi.org/10.1016/j. margeo.2014.12.007

Kaniewski, D., Van Campo, E., Guiot, J., Le Burel, S., Otto, T. \& C. Baeteman, 2013: Environmental roots of the Late Bronze Age crisis.- PLoS One, 8, 8, e71004. DOI: https://doi.org/10.1371/journal.pone.0071004

Kaniewski, D., Van Campo, E., Paulissen, E., Weiss, H., Bakker, J., Rossignol, I. \& K. Van Lerberghe, 2011: 
The medieval climate anomaly and the little Ice Age in coastal Syria inferred from pollen-derived palaeoclimatic patterns.- Global and Planetary Change, 78, 3-4, 178-187. DOI: https://doi.org/10.1016/j.gloplacha.2011.06.010

Kelley, C.P., Mohtadi, S., Cane, M.A., Seager, R. \& Y. Kushnir, 2015: Climate change in the Fertile Crescent and implications of the recent Syrian drought.Proceedings of the National Academy of Sciences of the United States of America, 112, 11, 3241-3246. DOI: https://doi.org/10.1073/pnas.1421533112

Khusraw, N.I., 2003: Safar nameh.- Elmi Farhangi, pp. 224, Tehran.

Kroonenberg, S.B., Abdurakhmanov, G.M., Badyukova, E.V., Van der Borg, K., Kalashnikov, A., Kasimov, N.S., Rychagov, G.I., Svitoch, A.A., Vonhof, H.B. \& F.P. Wesselingh, 2007: Solar-forced $2600 \mathrm{BP}$ and Little Ice Age highstands of the Caspian sea.- Quaternary International, 173-174, 137-143. DOI: https:// doi.org/10.1016/j.quaint.2007.03.010

Kuzucuoğlu, C., Dörfler, W., Kunesch, S. \& F. Goupille, 2011: Mid-to late-Holocene climate change in central Turkey: the Tecer Lake record.- The Holocene, 21, 1, 173-188. DOI: https://doi. org/10.1177/0959683610384163

Lambton, A.K., 1996: Iran in Qajar era (translation S. Fasihi).- Javedan Kherad, Mashhad.

Lamy, F., Arz, H.W., Bond, G.C., Bahr, A. \& J. Pätzold, 2006: Multicentennial-scale hydrological changes in the Black Sea and northern Red Sea during the Holocene and the Arctic/North Atlantic Oscillation.- Paleoceanography, 21, 1. DOI: https://doi. org/10.1029/2005PA001184

Lauritzen, S.E., 1993: Natural environmental change in karst: the Quaternary record.- In: P.W. Williams (ed.) Karst Terrains: Environmental Changes and Human Impact. Catena Supplements, Volume 25, Catena, pp. 21-40, Stuttgart.

Leroy, S.A.G., Lahijani, H.A.K., Djamali, M., Naqinezhad, A., Moghadam, M.V., Arpe, K., Shah-Hosseini, M., Hosseindoust, M., Miller, C.S., Tavakoli, V. \& P. Habibi, 2011: Late Little Ice Age palaeoenvironmental records from the Anzali and Amirkola Lagoons (south Caspian Sea): Vegetation and sea level changes.- Palaeogeography, Palaeoclimatology, Palaeoecology, 302, 3-4, 415-434. DOI: https://doi. org/10.1016/j.palaeo.2011.02.002

Litt, T., Ohlwein, C., Neumann, F.H., Hense, A. \& M. Stein, 2012: Holocene climate variability in the Levant from the Dead Sea pollen record.- Quaternary Science Reviews, 49, 95-105. DOI: https://doi. org/10.1016/j.quascirev.2012.06.012

Mann, M.E., Zhang, Z., Rutherford, S., Bradley, R.S.,
Hughes, M.K., Shindell, D., Ammann, C., Faluvegi, G. \& F. Ni, 2009: Global signatures and dynamical origins of the Little Ice Age and Medieval Climate Anomaly.- Science, 326, 5957, 1256-1260. DOI: https://doi.org/10.1126/science.1177303

Medina-Elizalde, M., Burns, S.J., Lea, D.W., Asmerom, Y., von Gunten, L., Polyak, V., Vuille, M. \& A. Karmalkar, 2010: High resolution stalagmite climate record from the Yucatán Peninsula spanning the Maya terminal classic period.- Earth and Planetary Science Letters, 298, 1-2, 255-262. DOI: https://doi. org/10.1016/j.epsl.2010.08.016

Mertens, K.N., Bradley, L.R., Takano, Y., Mudie, P.J., Marret, F., Aksu, A.E., Hiscott, R.N., Verleye, T.J., Mousing, E.A., Smyrnova, L.L. \& S. Bagheri, 2012: Quantitative estimation of Holocene surface salinity variation in the Black Sea using dinoflagellate cyst process length.- Quaternary Science Reviews, 39, 45-59. DOI: https://doi.org/10.1016/j.quascirev.2012.01.026

Migowski, C., Stein, M., Prasad, S., Negendank, J.F. \& A. Agnon, 2006: Holocene climate variability and cultural evolution in the Near East from the Dead Sea sedimentary record.- Quaternary Research, 66, 3, 421-431. DOI: https://doi.org/10.1016/j. yqres.2006.06.010

Miller, C.S., Leroy, S.A., Collins, P.E. \& H.A. Lahijani, 2016: Late Holocene vegetation and ocean variability in the Gulf of Oman.- Quaternary Science Reviews, 143, 120-132. DOI: https://doi.org/10.1016/j. quascirev.2016.05.010

Miller, G.H., Geirsdóttir, Á., Zhong, Y., Larsen, D.J., Otto-Bliesner, B.L., Holland, M.M., Bailey, D.A., Refsnider, K.A., Lehman, S.J., Southon, J.R. \& C. Anderson, 2012: Abrupt onset of the Little Ice Age triggered by volcanism and sustained by sea-ice/ ocean feedbacks.- Geophysical Research Letters, 39, 2. DOI: https://doi.org/10.1029/2011GL050168

Ocakoğlu, F., Dönmez, E.O., Akbulut, A., Tunoğlu, C., Kır, O., Açıkalın, S., Erayık, C., Yılmaz, İ.Ö. \& S.A. Leroy, 2016: A 2800-year multi-proxy sedimentary record of climate change from Lake Çubuk (Göynük, Bolu, NW Anatolia).- The Holocene, 26, 2, 205-221. DOI: https://doi.org/10.1177/0959683615596818

Okazaki, S., 1986: The great Persian famine of 1870 71.- Bulletin of the School of Oriental and African Studies, 49, 1, 183-192. DOI: https://doi. org/10.1017/S0041977X00042609

Onac, B.P., Forray, F.L., Wynn, J.G. \& A.M. Giurgiu, 2014: Guano-derived $\delta^{13} \mathrm{C}$-based paleo-hydroclimate record from Gaura cu Musca Cave, SW Romania.- Environmental Earth Sciences, 71, 9, 4061-4069. DOI: http://dx.doi.org/10.1007/s12665-014-3124-x 
Onac, B.P., Hutchinson, S.M., Geantă, A., Forray, F.L., Wynn, J.G., Giurgiu, A.M. \& I. Coroiu, 2015: A 2500-yr late Holocene multi-proxy record of vegetation and hydrologic changes from a cave guano-clay sequence in SW Romania.- Quaternary Research, 83, 3, 437-448. DOI: https://doi.org/10.1016/j. yqres.2015.01.007

Perner, K., Moros, M., Jennings, A., Lloyd, J.M. \& K.L. Knudsen, 2013: Holocene palaeoceanographic evolution off West Greenland, The Holocene, 23, 3, 374-387. DOI: https:/doi. org/10.1177/0959683612460785

Pigolevskaia, N., 1975: Iranian history from ancient to the end of 1800 AC (translation K. Keshavarz).- Payam Publication, pp. 738, Tehran.

Ramezani, E., Marvie Mohadjer, M.R., Knapp, H.D., Ahmadi, H. \& H. Joosten, 2008: The late-Holocene vegetation history of the Central Caspian (Hyrcanian) forests of northern Iran.- The Holocene, 18, 2, 307-321. DOI: https:/doi. org/10.1177/0959683607086768

Ramezani, E., Mrotzek, A., Marvie Mohadjer, M.R., Kakroodi, A.A., Kroonenberg, S.B. \& H. Joosten, 2016: Between the mountains and the sea: Late Holocene Caspian Sea level fluctuations and vegetation history of the lowland forests of northern Iran.- Quaternary International, 408, 52-64. DOI: https://doi. org/10.1016/j.quaint.2015.12.041

Ramsey, C.B. \& S. Lee, 2013: Recent and planned developments of the program OxCal.-Radiocarbon, 55, 2, 720-730. DOI: https://doi.org/10.1017/ S0033822200057878

Reimer, P.J., Bard, E., Bayliss, A., Beck, J.W., Blackwell, P.G., Ramsey, C.B., Buck, C.E., Cheng, H., Edwards, R.L., Friedrich, M. \& P.M. Grootes, 2013: IntCal13 and Marine 13 radiocarbon age calibration curves 0-50,000 years cal BP.- Radiocarbon, 55, 4, 1869-1887. DOI: https://doi.org/10.2458/azu_js_ rc. 55.16947

Royer, A., Queffelec, A., Charlier, K., Puech, E., Malaizé, B. \& A. Lenoble, 2015: Seasonal changes in stablecarbon and nitrogen isotope compositions of bat guano (Guadeloupe).- Palaeogeography, Palaeoclimatology, Palaeoecology, 440, 524-532. DOI: https://doi.org/10.1016/j.palaeo.2015.09.033

Sanson, M., 1967: Itinerary (translation T. Tafazoli).- Ebnesina, pp. 238, Tehran.

Sarıkaya, M.A., Zreda, M. \& A. Çiner, 2009: Glaciations and paleoclimate of Mount Erciyes, central Turkey, since the Last Glacial Maximum, inferred from $36 \mathrm{Cl}$ cosmogenic dating and glacier modeling.- Quaternary Science Reviews, 28, 23-24, 2326-2341. DOI: https://doi.org/10.1016/j.quascirev.2009.04.015
Schmidt, A., Quigley, M., Fattahi, M., Azizi, G., Maghsoudi, M. \& H. Fazeli, 2011: Holocene settlement shifts and palaeoenvironments on the Central Iranian Plateau: investigating linked systems.The Holocene, 21, 4, 583-595. DOI: https:/doi. org/10.1177/0959683610385961

Sharifi, A., Pourmand, A., Canuel, E.A., Ferer-Tyler, E., Peterson, L.C., Aichner, B., Feakins, S.J., Daryaee, T., Djamali, M., Beni, A.N. \& H.A. Lahijani, 2015: Abrupt climate variability since the last deglaciation based on a high-resolution, multi-proxy peat record from NW Iran: The hand that rocked the Cradle of Civilization?.- Quaternary Science Reviews, 123, 215-230. DOI: https://doi.org/10.1016/j.quascirev.2015.07.006

Sharifi, A., Pourmand, A., Canuel, E.A., Naderi Beni, A. \& H.A. Lahijani, 2013: A 2400-year record of abrupt climate change from Almalou Crate Lake in NW Iran: Investigating the potential influence of solar variability on the climate of West Asia during late Holocene.- In: American Geophysical Union Environmental and Climatic Changes on a Human Time Scale: Varves and Other High-Resolution Sedimentary Records With Up to Decadal Resolution, 2013 Fall Meeting, $9^{\text {th }}-13^{\text {th }}$ December 2013, San Francisco.

Sharifi, M. \& Z. Hemmati, 2004: Variation in the diet of Mehely's horseshoe bat, Rhinolophus mehelyi, in three contrasting environments in western Iran.Zoology in the Middle East, 33, 1, 65-72. DOI: https://doi.org/10.1080/09397140.2004.10638064

Sharp, R.N., 2009: Commands of the Achaemenid Empire.- Pazineh publication, pp. 202, Tehran.

Stevens, L.R., Wright Jr, H.E. \& E. Ito, 2001: Proposed changes in seasonality of climate during the Lateglacial and Holocene at Lake Zeribar, Iran.The Holocene, 11, 6, 747-755. DOI: https://doi. org/10.1191/09596830195762

Stoetzel, E., Royer, A., Cochard, D. \& A. Lenoble, 2016: Late Quaternary changes in bat palaeobiodiversity and palaeobiogeography under climatic and anthropogenic pressure: new insights from Marie-Galante, Lesser Antilles.- Quaternary Science Reviews, 143, 150-174. DOI: https://doi.org/10.1016/j.quascirev.2016.05.013

Talebi, T., Ramezani, E., Djamali, M., Lahijani, H.A.K., Naqinezhad, A., Alizadeh, K. \& V. Andrieu-Ponel, 2016: The Late-Holocene climate change, vegetation dynamics, lake-level changes and anthropogenic impacts in the Lake Urmia region, NW Iran.- Quaternary International, 408, 40-51. DOI: https://doi. org/10.1016/j.quaint.2015.11.070

Tavernier, J., 1984: Itinerary Tavernier (translation A. Nori).- Sanayi library, pp. 719, Tehran. 
Taylor, L.R., 1963: Analysis of the effect of temperature on insects in flight.- Journal of Animal Ecology, 32, 1, 99-117. DOI: https://doi.org/10.2307/2520

R Development Core Team, 2013: R: A language and environment for statistical computing.- R Foundation for Statistical Computing, Vienna, Austria.

Tuttle, M.D. \& D. Stevenson, 1982: Growth and survival of bats.- In: T.H. Kunz (ed.) Ecology of bats. Springer, pp. 105-150, Boston. DOI: https://doi. org/10.1007/978-1-4613-3421-7_3

Ülgen, U.B., Franz, S.O., Biltekin, D., Çagatay, M.N., Roeser, P.A., Doner, L. \& J. Thein, 2012: Climatic and environmental evolution of Lake Iznik (NW Turkey) over the last 4700 years.- Quaternary International, 274, 88-101. DOI: https://doi.org/10.1016/j. quaint.2012.06.016

van Zeist, W. \& S. Bottema, 1977: Palynological investigations in western Iran.- Palaeohistoria, 19, 19-85.

Vasskog, K., Langebroek, P.M., Andrews, J.T., Nilsen, J.E.Ø. \& A. Nesje, 2015: The Greenland Ice Sheet during the last glacial cycle: Current ice loss and contribution to sea-level rise from a palaeoclimatic perspective.- Earth-Science Reviews, 150, 45-67. DOI: https://doi.org/10.1016/j.earscirev.2015.07.006

Walker, R.T. \& M. Fattahi, 2011: A framework of Holocene and Late Pleistocene environmental change in eastern Iran inferred from the dating of periods of alluvial fan abandonment, river terracing, and lake deposition.- Quaternary Science Reviews, 30, 9-10, 1256-1271. DOI: https://doi.org/10.1016/j.quascirev.2011.03.004

Weiss, H., 2017: 4.2 ka BP Megadrought and the Akkadian Collapse.- In: Weiss, H. (ed.) Megadrought and Collapse: From Early Agriculture to Angkor. Oxford University Press, pp. 93-160, Oxford. DOI: https:// doi.org/10.1093/oso/9780199329199.003.0004

Widga, C. \& M. Colburn, 2015: Paleontology and paleoecology of guano deposits in Mammoth Cave, Ken- tucky, USA.- Quaternary Research, 83, 3, 427-436. DOI: https://doi.org/10.1016/j.yqres.2015.01.008

Wilde, C.J., Kerr, M.A., Knight, C.H. \& P.A. Racey, 1995: Lactation in Vespertilionidae bats.- In: Racey, P.A. \& S.M. Swift (eds.) Ecology, Evolution, and Behaviour of Bats. Zoological Society of London Symposia 67, Oxford University Press, pp. 139-149, Oxford.

Williams, C.B., 1961: Studies in the effect of weather conditions on the activity and abundance of insect populations.- Philosophical Transactions of the Royal Society B, 244, 713, 331-378. DOI: https://doi. org/10.1098/rstb.1961.0011

Woodborne, S., Hall, G., Robertson, I., Patrut, A., Rouault, M., Loader, N.J. \& M. Hofmeyr, 2015: A 1000year carbon isotope rainfall proxy record from South African baobab trees (Adansonia digitata L.).- PLoS One, 10, 5, e0124202. DOI: https://doi. org/10.1371/journal.pone.0124202

Woodbridge, J. \& N. Roberts, 2011: Late Holocene climate of the Eastern Mediterranean inferred from diatom analysis of annually-laminated lake sediments.- Quaternary Science Reviews, 30, 23-24, 3381-3392. DOI: https://doi.org/10.1016/j.quascirev.2011.08.013

Wurster, C.M., Rifai, H., Haig, J., Titin, J., Jacobsen, G. \& M. Bird, 2017: Stable isotope composition of cave guano from eastern Borneo reveals tropical environments over the past 15,000 cal yr BP.- Palaeogeography, Palaeoclimatology, Palaeoecology, 473, 73-81. DOI: https://doi.org/10.1016/j.palaeo.2017.02.029

Yu, L. \& Z. Lai, 2014: Holocene climate change inferred from stratigraphy and OSL chronology of aeolian sediments in the Qaidam Basin, northeastern Qinghai-Tibetan Plateau.- Quaternary Research, 81, 3, 488-499. DOI: https://doi.org/10.1016/j. yqres.2013.09.006 